\title{
MENGAPA HARUS MENJADI GURU?
}

\section{Abstrak}

Banyak istilah atau ungkapan yang sering diberikan untuk memaknai keberadaan guru. Beberapa di antaranya yang dapat dicatat adalah yang mengatakan bahwa "Guru adalah sosok yang patut ditiru dan digugu", "Guru adalah panutan masyarakat", "Guru adalah orang tempat bertanya", "Guru yang bermutu menghasilkan bangsa yang bermutu", dan "Guru adalah pahlawan tanpa tanda jasa". Pada umumnya, semua ungkapan atau pernyataan mengenai guru dirasakan sangatlah menyenangkan dan sungguh-sungguh apresiatif. Namun, apabila ditanyakan kepada para guru, boleh jadi mereka akan mengatakan bahwa yang penting adalah kenyataannya. Untuk apa semanis madu, setinggi apa pun rasa pujian apabila dalam kenyataannya, para guru belum merasakan konkritisasinya dalam kehidupan sehari-hari mereka. Memang sampai dengan tahun 1970-an, profesi guru dirasakan sebagai profesi panggilan yang benar-benar menjadi pekerjaan pilihan atau idaman (selected profession). Dalam kaitan ini, pertanyaan tentang "Mengapa harus menjadi guru?" menjadi suatu pertanyaan yang menarik dan menggugah perhatian setidak-tidaknya bagi kalangan masyarakat yang peduli terhadap profesi guru. Mengapa kemudian, pertanyaan yang sama ini cenderung menjadi pertanyaan yang kurang atau bahkan tidak lagi menarik atau menggugah perhatian? Namun, akhir-akhir ini setidak-tidaknya pertanyaan yang lebih menarik perhatian dan juga mungkin menggugah perhatian adalah "Mengapa tidak harus menjadi guru?". Tulisan ini mencoba memberikan kajian singkat tentang berbagai aspek yang berkaitan dengan keberadaan guru dengan harapan akan dapat menjadi bahan pemikiran untuk pembahasan lebih lanjut.

Kata-kata kunci: profesi guru, iklim yang kondusif, kompetensi, kualifikasi, dan sertifikasi guru.

*) Drs. Sudirman Siahaan, M.Pd., adalah tenaga fungsional peneliti bidang pendidikan pada PUSTEKKOM-Departemen Pendidikan Nasional. 


\section{A. PENDAHULUAN}

Ada beberapa istilah atau ungkapan yang sering diberikan untuk memaknai keberadaan guru. Beberapa di antaranya yang dapat dicatat adalah yang mengatakan bahwa "Guru adalah sosok yang patut ditiru dan digugu", "Guru adalah panutan masyarakat", "Guru adalah orang tempat bertanya", "Guru yang bermutu menghasilkan bangsa yang bermutu", dan "Guru adalah pahlawan tanpa tanda jasa". Pada umumnya, semua ungkapan atau pernyataan mengenai guru dirasakan sangatlah menyenangkan dan sungguh-sungguh apresiatif. Namun, apabila ditanyakan kepada para guru bagaimana keadaan mereka yang sebenarnya, maka boleh jadi mereka akan mengatakan bahwa yang terpenting bukannya ungkapan atau pujian yang sedap dan menyenangkan hati tetapi bagaimana kenyataan hidup sehari-hari para guru.

Guru tidak mungkin sepenuhnya mengandalkan kehidupan keluarganya pada penghasilan yang diperoleh sebagai guru. Sudah sering dilansir di media cetak bahwa untuk memenuhi tuntutan kehidupan sehari-hari, maka beberapa guru di daerah perkotaan terpaksa harus tidak malu-malu untuk melakukan pekerjaan tambahan lainnya. Sebagai contoh, misalnya guru terpaksa mengajar di beberapa sekolah, guru memberikan les privat, guru menyambi (bekerja sambilan) sebagai sopir taksi, tukang ojek, atau membuka warung kecil. Karena itulah para guru dalam kehidupan sehari-harinya merasakan keberadaan mereka tidaklah semanis atau seindah makna dari berbagai ungkapan yang dikumandangkan tentang diri mereka sebagaimana yang telah dikemukakan di atas.

Demikian juga halnya dengan para guru yang berada di daerah pedesaan. Beberapa dari jenis pekerjaan tambahan yang mereka lakukan antara lain adalah bertani, berkebun, beternak, atau berdagang kecil-kecilan. Di sisi lain, keberadaan para guru sangatlah berarti dalam kehidupan bermasyarakat. Dalam kaitan ini, peranan guru menurut hasil identifikasi Isjoni adalah sebagai: (1) innovator penggerak pembangunan, (2) moderator berbagai 
permasalahan yang berkembang di masyarakat, (3) konseptor berbagai kegiatan di masyarakat, dan (4) motivator setiap proses pembangunan di masyarakat (Isjoni, 2005).

Apalah artinya bagi guru berbagai ungkapan atau pujian semanis madu, setinggi apa pun apabila dalam kenyataannya, mereka masih tetap saja harus berjuang untuk mencari pekerjaan tambahan lainnya kesana-kemari. Yang terpenting menurut guru adalah bentuk konkrit yang dapat mereka nikmati dalam kehidupan seharihari, yaitu kehidupan yang lebih baik sebagaimana yang pernah terjadi sampai dengan tahun 1970-an. Pada era tahun 1960-an sampai dengan 1970-an, profesi guru dirasakan sebagai profesi panggilan yang benar-benar menjadi pekerjaan pilihan atau idaman (selected profession). Karena itulah, maka pertanyaan "Mengapa harus menjadi guru?" menjadi suatu pertanyaan yang menarik dan menggugah perhatian masyarakat pada masa tersebut.

Kemudian, bagaimana keberadaan profesi guru setelah tahun 1970-an? Apakah profesi guru masih merupakan pekerjaan pilihan atau idaman? Dalam kaitan ini, tampaknya pertanyaan "Mengapa harus menjadi guru?" cenderung menjadi pertanyaan yang kurang atau bahkan tidak lagi menarik atau menggugah perhatian masyarakat. Tulisan ini mencoba memberikan kajian singkat tentang berbagai aspek yang berkaitan dengan keberadaan guru dengan mengajukan pertanyaan "Mengapa harus menjadi guru?" atau "Mengapa tidak harus menjadi guru?" dengan harapan dapat menjadi bahan pemikiran untuk pembahasan lebih lanjut.

\section{B. KAJIAN LITERATUR}

\section{Guru dan Keberadaannya}

\section{a. Guru dengan Masa Kejayaannya}

Sebagaimana kita pahami bersama bahwa guru merupakan kelompok orang yang diakui sangat berperan dalam menentukan kualitas bangsa sejalan dengan ungkapan 
bahwa "Guru yang bermutu menghasilkan bangsa yang bermutu". Tentunya belum hilang dari catatan kita tentang sekelumit kisah guru yang tidak hanya dihargai di Indonesia tetapi juga dihargai dan dibutuhkan oleh negara tetangga kita Malaysia.

Pada era tahun 1960-an, pemerintah Malaysia membutuhkan banyak tenaga guru Indonesia untuk mengajar di berbagai jenjang pendidikan di Malaysia. Dalam kaitan ini, Pemerintah Indonesia merespons positif permintaan negara tetangga ini dengan mengirimkan para guru dan dosen Indonesia untuk mengajar di Malaysia. Tampaknya tidak hanya guru yang dipentingkan Malaysia, tetapi juga mendidik para calon guru. Kepada para lulusan Sekolah Menengah Malaysia diberikan beasiswa untuk belajar di berbagai universitas dan lembaga pendidikan tinggi yang menghasilkan guru (Lembaga Pendidikan Tenaga Kependidikan atau LPTK) di Indonesia.

Kebijakan yang ditempuh Pemerintah Malaysia pada tahun 1960-an jelas memperlihatkan betapa penting dan strategisnya posisi atau keberadaan guru dalam kehidupan berbangsa. Pemerintah Malaysia tidak hanya mengirimkan guru-gurunya untuk mengikuti pendidikan lanjutan, tetapi secara simultan juga mengirimkan para lulusan Sekolah Menengah untuk mengikuti pendidikan guru, Untuk tetap menjaga keberlangsungan kegiatan belajar-mengajar, di sisi yang lain, pemerintah Malaysia mendatangkan tenaga guru Indonesia yang tentunya dinilai bermutu untuk mengajar di Malaysia.

Bagaimana kita menyikapi kondisi tersebut di atas? Apakah kita akan dengan bangga mengatakan bahwa bangsa Indonesia pada umumnya dan para guru khususnya adalah sumber daya manusia yang bermutu (atau "lebih pintar" dari Malaysia)? Mungkin pada era tahun 1960-an tersebut ada 
benamya bahwa guru kita atau bangsa kita "lebih bermutu" sehingga Malaysia mengimpor guru Indonesia dan sekaligus juga mengirimkan para lulusan sekolah menengah untuk belajar di berbagai perguruan tinggi Indonesia. Apakah kita "terlena" dengan kebanggaan era tahun 1960-an dan menjadi "lupa" untuk memposisikan keberadaan guru kita seperti yang dilakukan pemerintah Malaysia?

Pada era tahun 1960-an, profesi guru menjadi suatu profesi yang banyak diminati sehingga seleksinya juga relatif ketat. Itulah sebabnya bahwa untuk dapat diterima dan mengikuti pendidikan di lembaga pendidikan guru adalah para lulusan terbaik dari sekolah menengah (rangking 1 sampai dengan 3) (Isjoni, 2005). Atau dengan kata lain dapat dikatakan bahwa pada era inilah guru mengalami masa kejayaannya. Bagaimana dapat terjadi masa kejayaan guru atau bagaimana bangsa Indonesia berhasil mencetak guru yang bermutu? Dalam kaitan ini, Isjoni mengemukakan bahwa pendidikan di Indonesia pada era tahun 1960-an dapat dikatakan bermutu karena memang diasuh oleh guru-guru yang bermutu.

Pendapat Isjoni tersebut di atas didasarkan atas beberapa keadaan empirik pada era tersebut, yang antara lain adalah:

1) lembaga pendidikan guru menerima siswa yang mendapat dominasi atau ranking tertinggi Quara 1 sampai 3).

2) selama mengikuti pendidikan guru, para siswa mendapat beasiswa atau tunjangan ikatan dinas (TID).

3) selama mengikuti pendidikan guru, para siswa diasramakan sehingga dapat mengoptimalkan pemanfaatan berbagai sumber belajar yang tersedia.

4) setelah menyelesaikan pendidikan (lulus), para lulusan pendidikan guru langsung ditempatkan sebagai guru (tidak perlu melamar pekerjaan kesana kemari) (Isjoni, 2005). 
Profesi guru merupakan profesi yang diminati dalam arti tidak hanya terbatas dalam bingkai status atau prestise sosial tetapi juga mencakup tingkat kesejahteraannya. Menjadi guru di kalangan para lulusan Sekolah Menegah Pertama atau Sekolah Menengah Atas merupakan pilihan yang diperebutkan.

Lembaga pendidikan guru pada era tersebut antara lain adalah Sekolah Guru Bawah (SGB), Sekolah Guru Atas (SGA), dan sekolah yang menghasilkan guru pemegang B-1 dan B-2. Mengingat para guru yang mengajar pada lembaga pendidikan guru ini adalah para lulusan sekolah guru yang bermutu dan para siswa yang dididik juga adalah siswa pilihan, maka hasil lulusannya juga adalah guru yang bermutu pula. Para guru yang dihasilkan oleh lembaga pendidikan guru ini pada umumnya sangat dihormati, dipuji, dan disegani tidak hanya oleh para siswa dan orangtua tetapi juga oleh masyarakat luas.

Begitu dihargai, disegani, dan dihormatinya sosok guru sehingga apabila ada seorang guru berjalan clan kebetulan akan berpapasan dengan siswa, maka yang terjadi adalah bahwa para siswa langsung mencari jalan lain untuk menghindar. Menghindar di sini menunjukkan perasaan segan atau hormat siswa kepada gurunya. Upaya menghindar berpapasan dengan guru akan dilakukan para siswa apabila memang ada alternatif untuk menghindar. Manakala tidak ada pilihan untuk menghindar berpapasan dengan guru, maka siswa dengan sikap santun akan berhenti di depan guru pada saat berpapasan dan memberi hormat kepada gurunya terlebih dahulu, barulah setelah itu siswa berlalu. Sikap yang diperlihatkan siswa ini menggambarkan perasaan sangat hormat siswa terhadap guru. 
Bentuk penghargaan lainnya terhadap sosok guru di kalangan masyarakat yang dapat dicatat adalah bahwa para orangtua yang mempunyai anak gadis cenderung untuk menikahkan anak gadisnya dengan guru. Kecenderungan orangtua ini dilandasi oleh suatu keyakinan bahwa sang putri yang dinikahkan dengan guru akan memiliki kehidupan yang lebih nyaman, tenteram, dan tingkat kesejahteraan sosial ekonomi yang relatif lebih baik.

\section{b. Penyikapan terhadap Profesi Guru}

Keberadaan profesi guru memerlukan penyikapan yang positif, yaitu yang menempatkan profesi guru sebagai profesi yang strategis, penting, dan menentukan. Sebagai konsekuensi dari bentuk penyikapan yang demikian ini, maka profesi guru tetap dijadikan sebagai profesi pilihan atau idaman sekalipun kondisi realitas yang ada dalam kehidupan sehari-hari dirasakan "masih memprihatinkan".

Sedangkan bentuk penyikapan lainnya adalah yang "menyama-ratakan" profesi guru dengan berbagai profesi atau pekerjaan lainnya. Profesi guru disikapi sebagai suatu profesi yang biasa-biasa saja, tidak ada istimewanya. Bahkan, ada bentuk penyikapan yang lebih ekstrim lagi, yaitu yang memperlakukan profesi guru sebagai suatu profesi yang dapat diemban oleh siapa saja yang mempunyai disiplin keilmuan tertentu. Dengan demikian, profesi guru ditempatkan atau diposisikan sebagai suatu profesi yang "lebih rendah" daripada berbagai profesi lainnya. Akibatnya, seseorang yang mempunyai latar belakang disiplin keilmuan tertentu, manakala mengalami kesulitan mendapatkan pekerjaan, maka mereka akan melirik pekerjaan sebagai guru.

Karena itu, tidaklah mengherankan apabila ada kecenderungan di kalangan para lulusan Sekolah Menengah untuk "tidak melirik" atau memilih profesi guru 
sebagai suatu pilihan hidup. Salah satu kemungkinannya dapat saja dikaremakan bahwa profesi guru bagi mereka "tidak atau kurang menarik perhatian" atau bahkan kemungkinan saja profesi guru itu "tidak terlintas" dalam pikiran mereka sewaktu menentukan pilihan selepas menyelesaikan pendidikan Sekolah Menengah, Kalaupun pada akhirnya ada di antara para lulusan Sekolah Menengah yang memilih untuk menekuni profesi guru, maka kemungkinan keadaan yang demikian ini dapat disebabkan karena kegagalan mereka meraih pilihan profesi yang dipandang lebih "menjanjikan" daripada profesi guru. Artinya, profesi guru bukanlah pilihan pertama atau unggulan bagi para lulusan Sekolah Menengah mefainkan pilihan yang "terpaksa" atau sebagai "pilihan ketimbang menganggur".

Manakala yang menjadi "input" lembaga pendidikan guru adalah para lulusan Sekolah Menengah yang karena "terpaksa" atau tidak ada pilihan lain ("pilihan ketimbang menganggur"), maka hasilnya kurang lebih tentulah "apa adanya". Setelah lulus mengikuti pendidikan guru, mereka ini masih memiliki pilihan apakah lebih tertarik untuk berkiprah sebagai guru atau justru meninggalkan profesi guru karena dinilai kurang menjanjikan. Kalaupun seandainya mereka ini terpaksa bekerja sebagai guru, maka kemungkinan hasil didikannya juga akan menjadi "apa adanya".

Masih akan bernilai tambah apabila dalam melaksanakan tugas profesionalnya sebagai guru, para guru "apa adanya" ini masih tergugah atau termotivasi untuk terus-menerus berupaya mendalami profesinya, baik melalui diskusi dengan sesama guru, mempelajari buku-buku yang relevan, maupun mengikuti berbagai pendidikan dan pelatihan guna lebih memantapkan pengembangan kualitas professional dirinya. Bagaimana jadinya apabila mereka 
ini menganut prinsip hanya sekedar melaksanakan tugas?

\section{c. Menjadikan Profesi Guru yang Prospektif}

Mengapa profesi guru pernah menjadi profesi yang menjanjikan (promising) sehingga menjadi profesi yang diidamkan sebagaimana yang terjadi pada era tahun 1960an? Beranjak dari beberapa catatan tersebut di atas, maka pertanyaan tentang "Mengapa harus menjadi guru?" tampaknya menjadi sesuatu yang menarik untuk dijadikan sebagai bahan pertimbangan dalam memilih profesi guru sebagai bidang profesi yang akan ditekuni. Menariktidaknya profesi guru dijadikan sebagai profesi pilihan sangatlah dipengaruhi oleh iklim yang kondusif yang berkembang di masyarakat mengenai keberadaan guru.

Iklim yang kondusif dimaksudkan di sini adalah pertamatama yang berkaitan dengan kebijakan pemerintah mengenai keberadaan profesi guru itu sendiri. Manakala kebijakan pemerintah menjadikan profesi guru sebagai profesi yang menjanjikan atau prospektif dalam kehidupan nyata sehari-hari, tentulah akan menggugah perhatian atau minat para siswa Sekolah Menengah untuk berkompetisi agar mereka dapat diterima untuk mengikuti pendidikan pada lembaga pendidikan guru.

Selain dukungan kebijakan pemerintah mengenai profesi guru yang kondusif, maka sikap dan apresiasi masyarakat yang positif mengenai keberadaan guru dalam kehidupan sosial sehari-hari akan turut juga menentukan profesi guru sebagai profesi pilihan. Mengapa? Karena mereka yang memilih untuk mengkhususkan diri mendalami profesi guru akan memiliki status kehidupan sosial yang diidamkan dan keberadaan mereka di masyarakat mendapat tempat yang khusus atau dihargai. Artinya, di kalangan masyarakat berkembang sikap dan perlakuan yang positif terhadap guru di mana guru sangat dihargai, disegani, diteladani, dan 
menjadi tempat masyarakat bertanya.

Melalui kebijakan pemerintah tentang keberadaan guru yang bersifat kondusif akan menimbulkan pengharapan baru, baik di kalangan mereka yang sudah menjadi guru maupun mereka yang akan menentukan pilihan menjadi guru. Perlakuan khusus dari pemerintah, baik yang berupa pemberian beasiswa untuk mengikuti pendidikan guru, penempatan kerja setelah berhasil menyelesaikan pendidikan guru (tidak lagi direpotkan untuk melamar kesana-kemari) maupun tingkat penghasilan yang diperoleh selama menjadi guru (jaminan kehidupan sosial ekonomi yang secara umum relatif lebih baik dibandingkan dengan profesi lainnya), akan cenderung menjadikan profesi guru sebagai profesi pilihan yang pertama dan terutama di kalangan para lulusan Sekolah Menegah.

Manakala keberadaan profesi guru sudah seperti tersebut di atas, maka dapatlah dikatakan bahwa baik secara sosial kemasyarakatan, psikologis, maupun ekonomis, setidaktidaknya profesi guru telah diarahkan menjadikan profesi yang dibutuhkan atau profesi idaman bagi para siswa Sekolah Menengah.

Bagaimana keadaan profesi guru akhir-akhir ini? Apakah profesi guru akan menjadi suatu profesi idaman atau yang dibutuhkan atau bahkan setidak-tidaknya mungkin menjadi salah satu profesi yang dipertimbangkan untuk dipilih ditekuni oleh para lulusan Sekolah Menengah? Apakah pertanyaan tentang "Mengapa harus menjadi guru?" masih menjadi suatu topik yang mengusik untuk diperbincangkan oleh para lulusan Sekolah Menengah pada khususnya dan masyarakat luas pada umumnya?

Dengan diberlakukannya Undang-Undang Nomor 14 Tahun 
2005 tentang Guru dan Dosen, maka topik pembahasan "Mengapa harus menjadi guru?" perlu diubah menjadi "Mengapa tidak harus menjadi guru?" Alasannya adalah bahwa dengan adanya Undang-Undang tentang Guru dan Dosen ini, maka telah mulai tampak adanya perhatian yang serius dari pemerintah terhadap keberadaan profesi guru. Harapan para guru adalah bahwa profesi guru akan menjadi suatu profesi yang lebih menjanjikan dibandingkan dengan profesi lainnya karena telah mulai tampak semakin dihargainya martabat guru di samping semakin membaiknya tingkat kesejahteraan guru (Sriyanto, 2006).

Sebagai salah satu contoh konkrit tentang upaya menjadikan profesi guru sebagai profesi yang prospektif adalah sebagaimana yang telah dirintis oleh Pemerintah Propinsi DKI Jakarta, yaitu memberikan tunjangan khusus kepada para guru. Peningkatan kesejahteraan guru untuk Propinsi DKI Jakarta telah dimulai sejak tahun 2005. Dundu dan Napitupulu mengemukakan upaya Pemerintah Propinsi DKI Jakarta yang secara konkrit dan bertahap telah mengupayakan peningkatan kesejahteraan guru yang besarnya dapat dilihat pada Tabel 1 berikut ini (Dundu dan Napitupulu, 2006).

Tabel 1. Peningkatan kesejahteraan guru di Propinsi DKI Jakarta sejak tahun 2005

\begin{tabular}{|l|l|r|r|r|r|}
\hline \multirow{2}{*}{ NO } & \multirow{2}{*}{ JENIS TUNJANGAN } & \multicolumn{2}{|c|}{ BESAR TUNJANGAN PER BULAN } & \multirow{2}{*}{ JUMLAH } \\
\cline { 3 - 5 } & & 2005 & 2006 & $2007 *)$ & \\
\hline 1. & Tunjangan kesejahteraan & $700.000 .-$ & -- & -- & $700.000 .-$ \\
\hline 2. & Tunjangan khusus & $300.000 .-$ & -- & -- & $300.000 .-$ \\
\hline 3. & $\begin{array}{l}\text { Tunjangan perbaikan } \\
\text { penghasilan }\end{array}$ & -- & $1.000 .000 .-$ & -- & $1.000 .000 .-$ \\
\hline 4. & Tambahan pengahasilan & -- & -- & $250.000 .-$ & $250.000 .-$ \\
\hline & JUMLAH & $1.000 .000 .-$ & $1.000 .000 .-$ & $250.000 .-$ & $2.250 .000 .-$ \\
\hline
\end{tabular}


*) Keterangan: Rencana peningkatan kesejahteraan guru tahun 2007 telah disampaian ke DPRD DKI Jakarta.

Memperhatikan tindakan konkrit Pemerintah Propinsi DKI Jakarta untuk menaikkan tingkat kesejahteraan guru secara bertahap sebagaimana yang tampak pada Tabel 1 di atas, maka secara bertahap masyarakat pada umumnya dan para para orangtua pada khususnya tentunya akan terdorong untuk mulai mengarahkan perhatian anakanaknya untuk memilih dan menekuni profesi guru. Bahkan para remaja yang tengah menyelesaikan pendidikannya pada satuan pendidikan Sekolah Menengah tentunya juga secara perlahan-lahan telah mulai tertarik dan "melirik profesi guru di wilayah DKI Jakarta yang prospektif'. Kebijakan Pemerintah Propinsi DKI Jakarta yang kondusif tentang keberadaan guru tentulah telah menjadikan profesi guru sebagai profesi yang menarik dan juga pilihan.

\section{Guru dan Tuntutan Kualifikasi}

\section{a. Guru dan Pendidikan Guru}

Untuk dapat menghasilkan guru dituntut adanya lembaga yang secara khusus mempunyai tugas dan fungsi untuk mempersiapkan atau mendidik para calon guru. Beberapa lembaga pendidikan yang pernah ada yang bertugas untuk mempersiapkan atau mendidik para calon guru Sekolah Dasar (SD) adalah Sekolah Guru Bawah (SGB), Sekolah Pendidikan Guru (SPG), dan Kursus Pendidikan Guru (KPG). Sedangkan untuk mendidik dan menghasilkan guru SMP atau SMA, diselenggarakanlah pendidikan B-1 atau B-2.

Lembaga pendidikan lainnya yang juga mempunyai tugas dan fungsi untuk mempersiapkan dan mendidik calon guru adalah Institut Keguruan dan Ilmu Pendidikan (IKIP) dan Fakultas Keguruan dan IImu Pendidikan di berbagai 
Universitas. Lembaga pendidikan inilah yang menghasilkan calon guru dengan masa belajar selama satu tahun (Diploma-1), masa belajar selama dua tahun (Diploma-II), masa belajar selama tiga tahun (Diploma-III), masa belajar selama empat tahun (Diploma-IV atau S-1).

Kebijakan berikutnya yang berkaitan dengan lembaga pendidikan guru adalah diubahnya status IKIP menjadi Universitas sehingga kita antara lain mengenal:

1) Universitas Pendidikan Indonesia (UPI) yang pada awalnya adalah IKIP Bandung;

2) Universitas Negeri Jakarta (UNJ) yang pada awalnya adalah IKIP Jakarta;

3) Universitas Negeri Semarang (UNES) yang pada awalnya adalah IKIP Semarang;

4) Universitas Negeri Yogyakarta (UNY) yang pada awalnya adalah IKIP Yogyakarta;

5) Universitas Negeri Malang (UM) yang pada awalnya adalah IKIP Malang;

6) Universitas Negeri Surabaya (UNESA) yang pada awalnya adalah IKIP Surabaya;

7) Universitas Negeri Medan (UNIMED) yang pada awalnya adalah [KIP Medan;

8) Universitas Negeri Makassar (UNM) yang pada awalnya adalah [KIP Ujung Pandang;dan

9) Universitas Negeri Manado (UNIMA) yang pada awalnya adalah IKIP Manado.

Perubahan juga terjadi pada lembaga pendidikan guru agama yang berada di bawah pengelolaanlpembinaan Departemen Agama. Institut Agama Islam Negeri (IAIN) sebagai salah satu lembaga pendidikan guru agama mengalami perubahan menjadi Universitas Islam Negeri (UIN). 
Sekalipun telah ada lembaga pendidikan guru, ternyata kebutuhan akan guru tidak selamanya dapat disediakan sehingga lahirlah kebijakan yang menuntut pengadaan guru secara mendesak (crash program). Kebijakan yang pemah diterapkan yang bersifat mendesak dalam pengadaan guru adalah Program Pendidikan Sekolah Lanjutan Tingkat Pertama (PGSLTP) untuk mempersiapkan calon guru SLTP dan Program Pendidikan Guru Sekolah Tingkat Atas (PGSLTA) untuk mempersiapkan calon guru SLTA.

Kebijakan yang juga dapat dicatat adalah bahwa untuk memiliki kualifikasi mengajar di SD dinilai tidak lagi memadai jika hanya memiliki latar belakang pendidikan guru yang setara dengan Sekolah Menengah. Karena itu, lembaga Sekolah Pendidikan Guru (SPG) yang bertugas untuk menghasilkan guru SD dilikwidasi atau ditutup. Demikian juga dengan keberadaan lembaga pendidikan Sekolah Guru Olahraga (SGO). Untuk menjadi guru SD, maka para calon guru harus mengikuti pendidikan selama 2 tahun yang diselenggarakan oleh lembaga pendidikan tinggi. Khasanah pendidikan guru bertambah dengan diberikannya tugas baru kepada beberapa perguruan tinggi untuk menyelenggarakan Pendidikan Guru Sekolah Dasar (PGSD).

Para guru SD yang berminat untuk meningkatkan kualifikasi pendidikannya dari yang semula hanya lulusan SPG, maka mereka dapat mengikuti program Diploma-II PGSD (inservice teacher training program). Bagi para lulusan Sekolah Menengah yang berminat menjadi guru SD, maka mereka boleh melamar untuk mengikuti pendidikan Diploma-II PGSD (pre-service teacher training program). Para mahasiswa yang mengikuti program PGSD ini, memang dirancang untuk menjadi guru kelas di SD bukan untuk menjadi guru bidang studi. 
Dengan kebijakan tersebut di atas, maka untuk menjadi seorang guru SD, maka seseorang setidak-tidaknya harus menghabiskan waktu selama 2 tahun untuk menyelesaikan pendidikan Diploma-II PGSD. Bagi para guru SD yang tidak memungkinkan untuk mengikuti pendidikan Diploma-II PGSD pada perguruan tinggi reguler, maka mereka dapat mengikuti pendidikan yang sama melalui sistem belajar jarak jauh yang ditawarkan oleh Universitas Terbuka (UT). Khusus bagi para guru SD yang berada di daerah yang sulit keadaan geografisnya atau jauh dari lokasi perguruan tinggi, maka Pusat Teknologi Informasi dan Komunikasi untuk Pendidikan (Pustekkom) bekerjasama dengan UT dan Direktorat teknis terkait menyelenggarakan program Diploma-II PGSD melalui Siaran Pendidikan atau yang lebih dikenal dengan program Diploma-II Siaran Pendidikan (DII SP).

Para guru SD yang mengikuti program D-II SP mendapatkan modul D-II PGSD dari UT untuk dipelajari secara mandiri. Para guru SD yang mengikuti program $D$ 11 SP tidak perlu lagi mengikuti kegiatan tutorial tatap muka karena kepada mereka telah diberikan bahan-bahan belajar tutorial yang dikemas dalam bentuk kaset audio dan video. Bahan belajar kaset audio dan video ini pada dasarnya dirancang untuk dimanfaatkan oleh para guru peserta D-II SP dalam bentuk kelompok-kelompok kecil. Sekalipun demikian, bahan belajar ini dapat juga mereka manfaatkan secara individual.

Mated pelajaran yang dikemas ke dalam media kaset audio dan video ini didasarkan atas hasil analisis terhadap bahan belajar yang terdapat di dalam modul yang dinilai benarbenar sulit dipahami oleh para guru. Para guru SD yang mengikuti program D-II SP ini tidak perlu mengeluarkan biaya karena semua kegiatan pembelajaran termasuk bahan-bahan belajarnya adalah ditanggung oleh pemerintah. 


\section{b. Guru dan Peningkatan Kompetensi}

Upaya peningkatan kompetensi guru terus-menerus dilaksanakan dari tahun ke tahun. Peningkatan kompetensi guru dapat dilakukan dalam bentuk yang konvensional, yaitu mengumpulkan guru di suatu tempat dan kemudian melatih mereka (pelatihan secara tatap muka). Bentuk pelatihan lain yang tidak konvensional adalah pelatihan yang diselenggarakan dengan menerapkan sistem belajar jarak jauh.

Bentuk-bentuk pelatihan guru melalui sistem belajar jarak jauh yang dilaksanakan oleh Pustekkom-Depdiknas dapat dikemukakan antara lain adalah: (1) pendidikan dan pelatihan guru melalui siaran radio (atau yang disebut sebagai: Diklat SRP Guru SD), (2) pendidikan Diploma-II guru SD melalui Siaran Pendidikan (D-II SP), dan (3) pendidikan dan pelatihan jarak jauh bahasa Inggris Guru SD yang diselenggarakan melalui kerjasama dengan Pusat Pengembangan Penataran Guru Bahasa (P3G Bahasa). Bahan belajar yang digunakan adalah bahan belajar mandiri tercetak (modul), kaset audio, dan video compact disc (VCD).

Di penghujung tahun 2006 ini (Desember 2006), Pustekkom melakukan ujicoba sistem pemanfaatan siaran TV yang bersifat interaktif melalui Satelit Siaran Langsung (SSL) untuk penyelenggaraan peningkatan kompetensi guru. Kegiatan ujicoba ini menggunakan satelit Telkom-I yang memungkinkan para guru di beberapa titik yang telah dilengkapi dengan antenna parabola dapat menangkap tayangan siaran dalam bentuk audiovisual. Sedangkan umpan balik dari para guru dilakukan melalui saluran telepon. 
Interaktivitas yang dikembangkan dalam ujicoba sistem peningkatan kompetensi guru melalui siaran TV adalah bahwa para guru di berbagai lokasi yang telah ditentukan dapat melihat gambar dan mendengar suara nara sumber dan pembawa acara (presenter) yang berada di Pustekkom; sebaliknya, nara sumber dan pembawa acara di Pustekkom hanya dapat mendengar suara para guru di berbagai lokasi yang mengajukan pendapat atau pertanyaan karena dilakukan melalui fasilitas telepon.

\section{c. Guru dan Peningkatan Kualifikasi}

Dengan disahkannya Undang-Undang tentang Guru dan Dosen, maka seorang guru setidak-tidaknya haruslah memiliki kualifikasi pendidikan Diploma Empat (D-IV) atau Strata Satu (S-1) agar dapat mengikuti program sertifikasi. Berkaitan dengan kualifikasi minimal guru (Diploma-IV atau Srata-1), Sriyanto mengemukakan bahwa dari hampir 2,7 juta guru di Indonesia, maka ternyata sekitar 1,8 juta guru $(66,67 \%)$ belum memenuhi kualifikasi minimal. Secara khusus pada satuan pendidikan SD, Sriyanto mengemukakan bahwa hanya $8,3 \%$ guru SD yang memenuhi kualifikasi minimal atau berpendidikan S-1 (Sriyanto, 2006).

Sedangkan Astuti dan Satrio mengemukakan bahwa secara umum, 15,21\% guru yang mengajar pada jenjang pendidikan dasar dan menengah tidak sesuai dengan kompetensinya. Apabila dilihat dari segi kesesuaian ijazah dengan ketentuan yang ada, maka keadaan guru yang mengajar pada pendidikan dasar dan menengah adalah seperti yang terdapat pada Tabel 2 berikut ini. 
Tabel 2.

Kesesuaian ijazah guru dengan ketentuan yang ada*)

\begin{tabular}{|l|l|c|c|}
\hline \multirow{2}{*}{ NO } & \multirow{2}{*}{ SATUAN PENDIDIKAN } & \multicolumn{2}{|c|}{$\begin{array}{l}\text { KESESUAIAN IJAZAH } \\
\text { DENGAN KETENTUAN }\end{array}$} \\
\cline { 3 - 4 } & & SESUAI & TIDAK SESUAI \\
\hline 1. & Sekolah Dasar (SD) & $33,89 \%$ & $66,11 \%$ \\
\hline 2. & Sekolah Menengah Pertama & $60,01 \%$ & $39,99 \%$ \\
\hline 3. & Sekolah Menengah Atas (SMA) & $65,92 \%$ & $34,08 \%$ \\
\hline
\end{tabular}

*) Sumber: Astuti dan Satrio, Kompas 22 Desember 2006.

Di samping ketidaksesuaian ijazah yang dimiliki guru dengan ketentuan yang ada, Astuti clan Satrio juga memberikan gambaran tentang latar belakang pendidikan guru Sekolah Dasar (SD) yang mengajar di 6 propinsi di pulau Jawa dengan guru yang mengajar di luar pulau Jawa sebagaimana yang terdapat pada Tabel 3 di bawah ini.

Tabel 3. Latar belakang pendidikan guru SD di dalam dan luar pulau Jawa

\begin{tabular}{|l|l|c|c|}
\hline NO & $\begin{array}{c}\text { LATAR BELAKANG } \\
\text { PENDIDIKAN (IJAZAH) }\end{array}$ & DALAM JAWA & LUAR JAWA \\
\hline 1. & Sarjana (S-1) & $31,20 \%$ & $15,20 \%$ \\
\hline 2. & Diploma & $44,90 \%$ & $53,50 \%$ \\
\hline 3. & SLTA/SPG & $23,70 \%$ & $31,00 \%$ \\
\hline
\end{tabular}

*) Sumber: Astuti dan Satrio, Kompas 22 Desember 2006.

Dengan merujuk pada Undang-Undang tentang Guru dan Dosen, maka dari Tabel 3 tersebut di atas jelaslah tampak bahwa sekitar 68,60\% guru di 6 propinsi di pulau Jawa dan sekitar $84,50 \%$ guru di luar pulau Jawa belum memenuhi kualifikasi pendidikan yang minimal. Artinya, lebih dari separuh guru SD yang ada perlu ditingkatkan kualifikasi 
pendidikannya apabila mereka akan mengikuti program sertifikasi guru.

Selain itu, hasil penelitian Purnomo Setiady Akbar yang dikutip Isjoni (Isjoni, 2005) mengemukakan bahwa jumlah guru yang tidak memenuhi kualifikasi pendidikan yang bersifat minimal untuk dapat mengikuti program sertifikasi guru adalah sebagai berikut:

1) sekitar $89 \%$ dari 1.049 .468 orang guru SD (atau sekitar 980.231 orang guru),

2) sekitar $57 \%$ dari 239.929 orang guru SLTP (atau sekitar 136.759 orang guru), clan

3) sekitar $26 \%$ dari 121.432 orang guru SLTA (atau sekitar 31.572 orang guru).

Informasi yang didasarkan atas hasil penelitian Purnomo Setiady Akbar tersebut di atas mengandung makna bahwa guru yang perlu ditingkatkan kualifikasi pendidikannya adalah sebagian besar guru yang mengajar pada satuan pendidikan SD. Sedangkan pada satuan pendidikan Sekolah Menengah Pertama (SMP), lebih dari separoh jumlah guru SMP memerlukan peningkatkan kualifikasi pendidikan manakala mereka akan mengikuti program sertifikasi guru. Dengan demikian, yang menjadi garapan dad program peningkatan kualifikasi pendidikan guru sangatlah besarjumlahnya.

Memperhatikan jumlah guru yang perlu ditingkatkan kualifikasi pendidikannya sangat besar, maka diperlukan berbagai usaha yang memungkinkan terjadinya percepatan dalam memenuhi tuntutan Undang-Undang. Tidak hanya upaya yang bersifat konvensional, tetapi juga upaya yang bersifat inovatif melalui penerapan prinsip-prinsip pendidikan terbuka clan jarak jauh perlu dikaji sehingga para guru, baik yang berada di daerah perkotaan maupun para guru yang berada di berbagai daerah yang terpencil 
atau sulit keadaan geografisnya, akan dapat menikmati hasil atau manfaat adanya Undang-Undang tentang Guru clan Dosen.

Bagi para guru yang telah memiliki Diploma-IV atau S-1 dan berhasil lulus dalam mengikuti program sertifikasi guru, maka kepada mereka akan diberikan hak mendapatkan tunjangan sebesar satu kali gaji pokok clan tambahan tunjangan fungsional sebesar Rp 500.000.- (lima ratus ribu rupiah) per bulan. Sedangkan para guru yang belum memiliki kualifikasi Diploma-IV atau S-1, maka mereka harus mengikuti kegiatan pendidikan Diploma-IV atau S-1 terlebih dahulu sebelum mengikuti program sertifikasi guru.

\section{PENUTUP}

Berbagai ungkapan atau pernyataan mengenai guru dirasakan para guru dan masyarakat pada umumnya sangatlah menyenangkan dan sungguh-sungguh apresiatif. Namun, apabila ditanyakan langsung kepada para guru, boleh jadi perasaan atau penyikapan para guru tentang berbagai ungkapan atau pujian mengenai did mereka akan berbeda. Kemungkinan saja para guru akan merespon dengan mengatakan bahwa yang terpenting bagi mereka adalah kenyataan hidup sehari-hari yang lebih baik.

Mengingat kondisi kehidupan nyata para guru yang relatif masih belum memadai telah memaksa mereka untuk melakukan pekerjaan sambilan. Pekerjaan sambilan bagi para di wilayah perkotaan, antara lain adalah: mengajar di berbagai sekolah, bekerja sebagai guru les privat, bekerja sebagai sopir taksi atau tukang ojek, maupun membuka warung kecil-kecilan. Sedangkan pekerjaan sambilan para guru di daerah pedesaan antara lain adalah: bertani, berkebun, beternak, atau berdagang kecil-kecilan.

Pada era tahun 1960-an, profesi guru masih menjadi suatu profesi yang dibutuhkan karena (1) adanya dukungan kebijakan 
pemerintah yang langsung menempatkan para lulusan sekolah pendidikan guru, (2) selama mengikuti pendidikan, para calon guru diasramakan clan diberi beasiswa (biaya pendidikan sepenuhnya ditanggung oleh pemerintah), (3) adanya sikap yang positif clan apresiatif dari kalangan masyarakat terhadap keberadaan para guru. Kemudian, profesi guru diperlakukan sebagai suatu profesi yang tidak ada bedanya (disama-ratakan) dengan berbagai profesi yang ada. Atau bahkan profesi guru diperlakukan sebagai suatu profesi yang lebih rendah atau yang "hanya akan dijadikan sebagai pilihan terakhir daripada tidak ada pekerjaan".

Dengan adanya Undang-Undang tentang Guru dan Dosen, maka sedikit banyak telah mulai turut meningkatkan status profesi guru. Terlebih lagi setelah Pemerintah Propinsi DKI Jakarta memberikan perlakuan yang khusus terhadap keberadaan, yaitu yang secara bertahap memberikan tunjangan perbaikan penghasilan. Kebijakan Pemerintah Propinsi DKI Jakarta secara bertahap akan menjadikan profesi guru sebagai suatu profesi yang menarik perhatian clan minat atau diidamkan oleh para siswa yang sedang menyelesaikan pendidikannya di SMA. Peningkatan penghasilan para guru tentulah menjadi salah satu faktor yang akan turut menjadikan profesi guru sebagai profesi yang prospektif clan diidamkan.

Pada dasamya, keberadaan guru dengan diberlakukannya Undang-Undang tentang Guru dan Dosen bukanlah semakin ringan tetapi justru semakin dituntut usaha keras dari para guru itu sendiri. Misalnya, para guru yang belum memiliki kualifikasi pendidikan Diploma-IV atau S-1, maka mereka harus pertama-tama mengikuti program peningkatan kualifikasi pendidikan. Tidak cukup hanya mengikuti program peningkatan kualifikasi pendidikan, tetapi mereka juga harus mengikuti program sertifikasi. Mereka yang telah berhasil memiliki kualifikasi pendidikan yang minimal dan lulus mengikuti program sertifikasi, maka barulah kepada mereka diberikan haknya untuk mendapatkan tunjangan sebesar satu kali gaji pokok dan tambahan tunjangan fungsional sebesar Rp 500.000.- (lima ratus ribu rupiah) per bulan. Konon hasil sertifikasi 
ini juga mempunyai masa berlaku sehingga kembali guru harus mengikuti uji sertifikasi.

Memperhatikan data tentang besarnya jumlah guru yang belum memenuhi kualifikasi pendidikan yang minimal untuk mengikuti program sertifikasi guru, maka tentunya diperlukan berbagai usaha percepatan untuk memenuhi tuntutan Undang-Undang tentang Guru clan Dosen sehingga para guru akan dapat menikmati hasil atau manfaatnya. Karena itu, dipandang tidak memadai jika hanya upaya yang bersifat konvensional yang akan ditempuh. Disarankan juga agar dilakukan pengkajian terhadap berbagai upaya yang bersifat inovatif melalui penerapan prinsip-prinsip pendidikan terbuka clan jarak jauh dengan memanfaatkan teknologi informasi dan komunikasi (TIK). Melalui pemanfaatan TIK diharapkan secara khusus akan dapat menjangkau para guru yang berada di berbagai daerah yang terpencil atau sulit keadaan geografisnya sehingga mereka ini juga akan dapat menikmati hasil atau manfaat adanya Undang-Undang tentang Guru dan Dosen.

Pertanyaan tentang "Mengapa harus menjadi guru?" pada kurun waktu tertentu boleh jadi merupakan ungkapan atau pernyataan yang secara "apriori atau sinis" dikemukakan banyak orang karena kenyataannya profesi guru bukanlah sebagai profesi yang menjanjikan (prospektif). Namun, dengan adanya Undang-Undang tentang Guru clan Dosen yang kemudian dikuti dengan kebijakan Pemerintah Propinsi DKI Jakarta yang secara konkrit dan bertahap meningkatkan kesejahteraan para guru, maka tentunya pertanyaan masyarakat banyak tentang "Mengapa harus menjadi guru?" tentulah akan berubah menjadi ungkapan atau pemyataan "Mengapa tidak harus menjadi guru?".

\section{DAFTAR KEPUSTAKAAN}

Astuti, Palupi P dan BE Satrio. (2006). Reformasi Pendidikan Tambal Sulam. Harian Kompas 22 Desember 2006, halaman:14 
Dundu, Pingkan Elita dan Ester Lince napitupulu. (2006). "Jakarta Boleh Bangga tetapi ... n. Harian Kompas 15 Desember 2006. Isjoni. (2005). Citra Guru: Antara Tuntutan dan Pengabdian, Pekanbaru: Penerbit UNRI Press. Sriyanto, HJ. (2006). "Siapa Bilang Jadi Guru itu Gampang". Harian Kompas 4 Desember 2006. Wahyudi, FA Agus. (2006). Anomali Pendidikan. Harian Kompas 11 Desember 2006. 